\title{
ECOLOGICAL CONSEQUENCES OF UNDERGROUND MINING THIN COAL SEAMS IN THE WESTERN DONBASS
}

\author{
Mykhailo Petlovanyi ${ }^{1}$ \\ Dmytro Malashkevych ${ }^{2}$
}

\section{DOI: https://doi.org/10.30525/978-9934-588-84-6-19}

Today, the coal industry is of great importance in ensuring energy independence of Ukraine, occupying a share of 37\% in the total electrical energy generation of the state. The main difficulty in mining the balance coal reserves is that almost $80 \%$ of them are concentrated in coal seams with a thickness of less than $1.0 \mathrm{~m}$. The problem of coal mining from thin seams is particularly acute in the Western Donbass mines. PJSC «DTEK Pavlohradvuhillia» is the leader of the Ukrainian coal industry, whose mines annually produce more than $60-70 \%$ of all Ukrainian coal, within the range of 18-20 million tons [1, p. 16; 2, p. 917].

Having analysed the geological base, it has been revealed that more than $50 \%$ of 775 million tons of industrial reserves are in the seams with a geological thickness of $0.55-0.80 \mathrm{~m}$. And only $3 \%$ or 23 million tons of coal is in the seams with a thickness of more than $1.0 \mathrm{~m}$, limiting significantly the service life of many mines in this area.

The current conventional technology of machine mining of thin bedding coal seams in the Western Donbass does not provide for backfilling of the mined-out underground space in mines with waste rocks and is not suitable for coal mining through the entire geological thickness of the seam (in 2018 the average geological thickness was $0.83 \mathrm{~m}$ ) [3, p. 3]. This leads to the forced cutting of the seam bottom rocks and a significant increase in the ash content of the mined coal.

As a result of the technological process of thin bedding coal seams underground mining, the environment of the Western Donbass coalmining region is experiencing environmental damage: the waste rock dumps are accumulated on the daylight surface, then surface subsidence occurs, leading to flooding and water-logging of territories.

Waste rock dumps accumulation. As a result of underground mining of coal seams, the waste accumulations are formed on the daylight surface in the form of waste rock dumps [4, p. 1331], formed mainly by waste rocks

${ }^{1}$ Dnipro University of Technology, Ukraine

2 Dnipro University of Technology, Ukraine 
from mine workings. Thus, during the industrial mining of coal seams in the Western Donbass, 11 waste dumps have been formed, in which more than 100 million tons of waste rock have been accumulated, over an area of more than 200 hectares [5, p. 148].

Mining of coal seams with low geological thickness linearly contributes to the high level of coal ash content, as a result of which it becomes necessary to perform a cycle of beneficiation. Thus, the rock dumps of mines are replenished with additional waste rock volumes along with the stockpiled rocks after mine workings. In the Western Donbass mines 4.0-4.5 million tons of rock is added per year, with an average ash content in mines of $43 \%$.

Waste rock accumulations occupy valuable agricultural land, lead to environmental pollution, and mining enterprises pay an environmental payment for every 1 ton of stockpiled rock. Rock dumps of mines spoil the landscapes of the earth's surface, pollute the atmosphere with dust and gases. Annually, about 400 tons of rock is washed out and blown out from each waste heap, and about 8 tons of salts are leached [6, p. 4; 7, p. 85].

Directions for the waste dumps disposal are the use of rocks as a material for backfilling underground cavities [8, p. 183; 9, p. 21; 10, p. 6235] or ravines, deformed earth's surfaces, and the like. Waste rock is also a raw material for obtaining many types of building materials [11, p. 184] lightweight aggregates for concrete (expanded clay, gravel, aggloporite), aggregates for ordinary concrete, large and small binding materials, bricks, tiles, glass-ceramic materials, materials for road construction and various other coatings for the production of mineral wool, etc.

Flooding of areas as a result of their undermining by mining operations. A significant problem in mining of all coal seams reserves is the earth's surface subsidence, which occurs as a result of the shift trough formation, especially in case of mining without backfilling the mined-out space.

The ecological problems of underground mining the coal reserves are evidenced by the example of Ternivka city and Bohdanivka village, located in the coal-mining Western Donbass region, Dnipropetrovsk oblast, which are surrounded by mining operations in the Ternivska, Samarska, Zakhidno-Donbaska mines. In the area of Bohdanivka village, there is a site of monitoring for flooding, where all changes with respect to the level of the daylight surface in the region are recorded (Figure 1). 


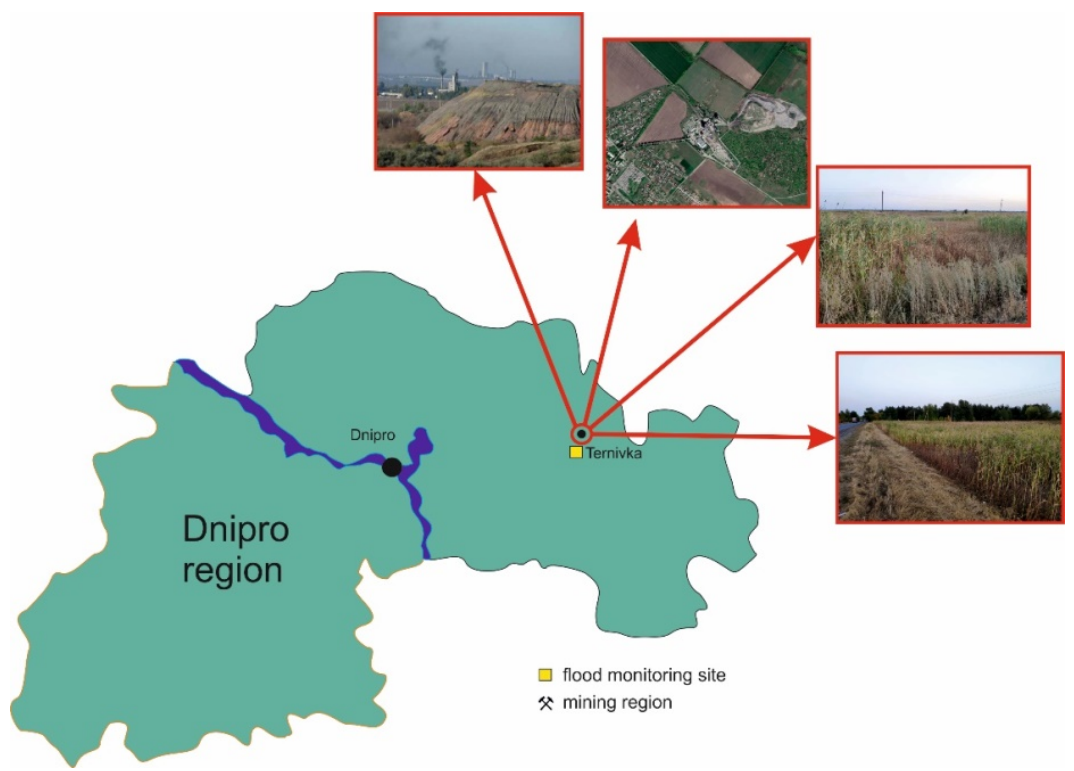

Figure 1. A visual representation of the ecological consequences from underground coal mining in the area of Ternivka city and Bohdanivka village: accumulation of waste rock dumps and flooding of the territory

As a result of the undermined areas subsidence, the groundwater level has increased, leading to water-logging and the formation of a flooding zone with an area of about $17.0 \mathrm{~km}^{2}$. The depth of the groundwater level in the flooded areas ranges from 1.1 to $3.0 \mathrm{~m}$. Based on the annual monitoring for the level of daylight surface and groundwater, it has been revealed that, compared to 2018, the surface subsidence increased by $0.15 \mathrm{~m}$, while no measures to prevent flooding are observed [12, p. 197]. Also, according to some data, the earth's surface subsidence in the Samara River floodplain reaches $7.5 \mathrm{~m}$. Similar processes tend to occur when mining the reserves in other 7 mines of the Western Donbass.

Therefore, a priority for the coal mining industry, the production activity of which adversely affects the ecological state of the environment, is to develop a progressive and low-waste technology for mining the coal reserves with backfilling the mined-out space of mines with the waste rocks, thereby minimizing the surface deformations. 
Riga, Latvia, September 25, 2020

\section{References:}

1. Barabash, M., \& Cherednichenko, Y. Y. (2015). Transformation SHC «Pavlogradvugillia» in the world class coal-mining company - PJSC «DTEK Pavlogradvugillia.» Mining of Mineral Deposits, vol. 9, no. 1, pp. 15-23. doi: https://doi:10.15407/mining09.01.015

2. Petlovanyi, M. V., Lozynskyi, V. H., Saik, P. B., \& Sai, K. S. (2018). Modern experience of low-coal seams underground mining in Ukraine. International Journal of Mining Science and Technology, vol. 28, no. 6, pp. 917-923. doi: https://doi:10.1016/ j.jimst.2018.05.014

3. Snihur, V., Malashkevych, D., \& Vvedenska, T. (2016). Tendencies of coal industry development in Ukraine. Mining of Mineral Deposits, vol. 10, no. 2, pp. 1-8. doi: https://doi:10.15407/mining10.02.001

4. Haibin, L., \& Zhenling, L. (2010). Recycling utilization patterns of coal mining waste in China. Resources, Conservation and Recycling, vol. 54, no. 12, pp. 1331-1340. doi: https://doi.org/10.1016/j.resconrec.2010.05.005

5. Petlovanyi, M. V., \& Haidai, O. A. (2017). Analiz nakopychennia i systematyzatsiia porodnykh vidvaliv vuhilnykh shakht, perspektyvy yikh rozrobky [Analysis of accumulation and systematization of waste heaps of coal mines, prospects of their development]. Heotekhnichna Mekhanika, no. 136, pp. 147-158.

5. Hrinov, V. H., Khorolskyi, A. O., \& Kaliushchenko, O. P. (2019). Rozroblennia ekolohichnykh stsenariiv efektyvnoho osvoiennia tsinnykh rodovyshch korysnykh kopalyn [Development of ecological scenarios of effective development of valuable mineral deposits]. Mineral Resources of Ukraine, no. 2, pp. 46-50.

6. Zborshchyk, M. P., \& Il'yashov, M. A. (2007). O neotlozhnosti resheniya problem geoekologii Donbassa: global'nye problemy i ekologiya ugledobyvayushchikh regionov Ukrainy [On the urgency of solving the problems of geoecology of Donbass: global problems and ecology of coal-mining regions of Ukraine]. Coal of Ukraine, no. 12, pp. 3-6.

7. Chetverik, M. S., \& Bubnova, E. A. (2010). Formirovanie tekhnogennoy geologicheskoy sredy i ee vzaimosvyaz's prirodnoy [Formation of technogenic geological area and its interrelation with natural]. Journal of Kryvyi Rih National University, no. 25, pp. 83-87.

8. Kuzmenko, O., \& Petlovanyi, M. (2015). Substantiation the expediency of fine gridding of cementing material during backfill works. Mining of Mineral Deposits, vol. 9, no. 2, pp. 183-190. doi: https://doi:10.15407/mining09.02.183

9. Bondarenko, V., Ruskykh, V., Yarkovych, A., \& Malashkevych, D. (2014). On the question of rock leaving in worked-out area of coal mines. Mining of Mineral Deposits, vol. 8, no. 1, pp. 19-24. doi: https://doi:10.15407/mining08.01.019

10. Zhu, X., Guo, G., Liu, H., \& Yang, X. (2019). Surface subsidence prediction method of backfill-strip mining in coal mining. Bulletin of Engineering Geology and the Environment, vol. 78, no. 8, pp. 6235-6248. doi: https://doi:10.1007/s10064-019-01485-3

11. Shreekant, R. L., Aruna, M., \& Vardhan, H. (2016). Utilisation of mine waste in the construction industry - a critical review. International Journal of Earth Sciences and Engineering, vol. 09, no. 01, pp. 182-195. doi: https://doi:10.15407/mining08.01.019

12. Rehionalna dopovid pro stan navkolyshnoho pryrodnoho seredovyshcha $\mathrm{v}$ Dnipropetrovskii oblasti za 2019 rik [Regional report on the state of the environment in the Dnipropetrovsk region for 2019] (2019). Dnipro: Department of Ecology and Natural Resources of Dnipropetrovsk Regional State Administration, 320 p. (in Ukrainian) 